\title{
A Literature Study on Access of Petty Cash in Financial Crisis Private Sector
}

\author{
Dr. Uma Shankar Singh \\ Faculty of Administrative Sciences and Economics, Tishk International University, Erbil-Kurdistan
}

\begin{abstract}
Study presented here is a qualitative research based on the exploration of conceptual base of the study concentrating on the importance of petty cash in the business when it comes to private sector companies. The specific study is done Kurdistan region where the ISIS crisis has affected the business. Public sector companies are well equipped to take care of their activities by the support of government but private parties are facing many challenges as the financial crisis has effected banks and financial institutions as well. Here for the support of literature a company has been taken for study as the sample for understanding of the reality as stated by the literature. This study has the good combination of theoretical base with the practical understanding of the application. The study concludes as the companies and organization should making the cash as more of the percentage of the financial transition because of the access of petty cash has power and actions for companies finance situation and to better finance situation. The companies and private sector organization should make the cash flow statement with correct amount implementation to be positive points for fixing the financial crisis. The companies and private sector organization should making the sales by cash amount opposite that the loan (accounts payable) way.
\end{abstract}

Keywords: Petty cash, crisis, finance, private company, investment

DOI: $10.7176 /$ RJFA/10-10-02

Publication date:May $31^{\text {st }} 2019$

\section{Introduction}

According to Bordo et al (2001) said that Financial crisis have been started for the many years, but the bigger feeling the financial crisis in the summer 200 (Singh and Sahin, 2015), Financial crisis was com e as great surprise to the most of people and the difficult seen was in the United states of America (Singh, 2015), it was part of the more target of the markets. The propose of this research is to make an onions regarding this case of the financial crisis and buy which type of the systems can to reform the sectors specially in private sectors to be anti-Financial Crisis and each company and organization could use it as to be a strong circles around each of the countries and system of the rules and organizations specially the private one (Singh and Azad, 2019), the governmental organization is not so far regarding the effects of this phenomena also have same factors regarding the financial crisis but the reform of it and taking feedback of any transactions will be some easier regarding the private sectors because of the government of country will help the governmental organizations directly and quickly to return back in the same of lines before the financial crisis happen it (Singh, Mishra and Mishra (2014), but the private sector will get and receive the benefits of the governmental reform for the effectives of the financial crisis was happen its slowly and indirectly from the government because of this points the researcher find that the access of the petty cash its one of the points that effected of financial Crisis happen in the private sectors and ongoing with bad situations in the all kind of the statements in the companies that they targets is making a profit parallel with the current situation in the governments sectors and Growth Domestic product (GDP) level in the any country (Prasad et al., 2005). According to McKibbin and Stoeckel (2010) report that financial crisis happen and caused because of August 2007 September 2008 there was agreements between the investors in the US with the poor people regarding the mortgage industry (Singh, and Mishra, 2013), according this explanation the problem was happened (Financial Crisis), also access cash in the banks have basic rules inside the explanation (Singh and Sahin, 2015).

Because of the poor people buying and buildings the houses (it was dreams before this agreements) they are started to borrow the funds and they own amounts as cash amounts in the bank to the mortgage sector in the markets in this example we can analysis that the bank is private sectors and the access petty cash it's a funds and main the problem and effects of financial crisis was happened and caused in United State of America during the time, day by day the powers of petty cash was decreased inside the banks and outside of the banks (Singh, 2015), in front of the of this the cash amounts was going to outside countries (Singh, and Padhi, 2013), the cash transactions between the business to business, business to the customers by Surarchith, and Singh, (2013), business to markets ,market to markets and customer to markets was decreased by a big percentage of general cash transactions by Singh and Sahin, (2019). The economies in many countries in Asia and in Europe were drastically affected even though their banks had very little exposure to United State of America especially in the security of the access petty cash circulation and the size of cash amount inside the safe box in the central bank of the America (Sahin and Singh, 2018). In Japan, for example, Growth Domestic product (GDP) fell by 4 percent in the first quarter of 2009 as stated by Singh, and Yadav, (2013). Less extreme drops in industrial production and Growth 
Domestic product (GDP) than those experienced in Japan were occurring all over the world and the world economy began to gradually fail (Baker, 2007; Singh and Hamadamin, 2019).

\section{Literature Review Financial crisis}

According to Ross (2016) reported that the 21st century has proven to be as economically tumultuous as the two preceding centuries, with multiple financial crises striking nations, regions and, in the Great Recession (Singh and Bradosti, (2015), the entire global economy by Singh and Sahin, (2019). All financial crises share certain characteristics, but each tells its own unique story and has its own unique lessons for the future (Singh, 2015). A financial crisis is a generalized term for systemic problems in the larger financial sector of a country or countries (Bradosti and Singh, (2015). Financial crises often, but not always, lead to recessions. A fiscal crisis, on the other hand, refers to a balance-sheet problem with a government or multiple governments. If the debt load of a government creates funding or performance issues, it may be said to experience a fiscal crisis (Ross, 2016). If the capitalism countries for example: United States of America borrows too much and finds itself shut out of credit small business (Diwan, 2001). Financial Crisis and Fiscal Crisis can happen naturally without any help for the any sectors in any country almost parallel with economy crisis , but the fiscal crisis with a link government with country and give a role about the financial crisis by direct way and some time by the indirect way, mainly in the government responsibility regarding this case properly affect to the quarterly to budget of any government and specially make a negative point regarding the blocking saving amounts of central bank, reducing and decreasing it with decreasing the powers the amounts the markets as capital with decreasing the value of the local country currency (Eichengreen and Bordo, 2002). In between 2007 to 2009 global financial crisis was happened because of the bad result of the economy crisis with the decreasing level of developments (Singh, and Pratap, (2013), the global financial crisis 2007-2009 ignited in the one of the biggest and huge capital in the world and then transferred to the most of the development country especially in European Country (Goldin, and Vogel, 2010). The effects of global financial crisis will be submit up as following value Sherwani and Singh, (2015); in the part of the world wide economy as a characters has only make a relationship and contacted just around the circle of the fiscal years, that year was 2009 , because of the global growth domestic product (GDP) shrank from $\$ 63.07$ trillion to $\$ 59.78$ trillion (Ross, 2016; Singh, 2015; Singh and Bradosti, (2015).

According to Brigham and Ehrhardt (2013) said that consider how the equilibrium level of revenue is determined in the first stage of selecting budget when the owner of some person decision how to start the investment (Bradosti and Singh, 2015), this is mean that financial statement as budgeting is so importance for selecting the financial and economical steps in any organization generally and private sector specially of course the important statements for the investment as financial statement is free cash flow :The cash flow available distribution to investors (Singh, 2018), this is mean that we have focused on financial statements as common points in annual reports by Singh and Sahin, (2015), when the investor studied the financial statements should fell that some crisis will happen in the near of future if the globally situations for private sectors is going to bad because of some kind of weakness in the inside the interior environmental (Singh and Mishra, 2014), with studied the bad situation in the external eniveronmetial out side of the companies such as the international bad relationship or starting the war between some kind of countries when the investors went by those important points mentioned before (Singh, (2013), this is mean the investors can make important in the project management of the investment going to planning and controlling by using the strategy and opportunity for making a decision (goal) for starting the investment before spread the financial in details regarding the relation between investment and financial crisis the investment is going to financial statement then divide in to Cash flow, profit loss and Balance sheet also each companies have planning of the project consisted of External and internal planning, also external include controlling and opportunity, on the other hand for internal planning is composed of controlling and strategy of the project. In addition to the goal of company to have information for financial crisis for each investment also the company will take the feedback for the starting and growing the investment of the project (Kahle and Stulz, 2013).

\section{Financial status of private sector in Kurdistan during crisis}

The Kurdistan region government (KRG) has the possibility to reform accelerated economic development and growth in the more of the sectors in the economy, it is wished that Kurdistan region government (KRG) uses that suggested form and common economy development evaluated to implement this recommendation in very soon as possible (The report of the problems of Kurdistan region government (KRG) and Iraq budget 2013, comity of finance and economic and investment) stated by Singh and Kamaran, (2016). After to 2003 saving Iraq, it was good chance for Kurdistan region government for found more source of the capital in the budgeting by generally governments directly and going to the private sector indirectly, I am such as researcher believe that indirectly in the decreasing budgeting mean that any amounting accepting in the yearly budget by government and parliament also will be distributed by practically part by part and section by section inside the operation cost and investment cost directly, this amount will come to the economy circulation inside the markets and give more activity and 
powers and movements for the all kinds in different sector in the market such as real estate agency ,construction sectors, trade sector etc. more of worldwide companies decided to come Kurdistan region government zone for starting and making investment such as Shell oil company after opening and growth in the yearly budget in KRG government, also the internal company was grow and developed they capitals in annual budget specially those company have a link a governorate for making a projects by cash payments of the amounts from government to the private sector inside Kurdistan region government (KRG) (The official website of Kurdistan region government, 2016) by Singh and Mishra, (2015).

According RTI international (2008) reported that the capital budgeting in the private sector will be positive impact of the economic sectors, the impact side of the economy grow in KRG specially started with making the additional sectors of proofing the yearly budget of (Kurdistan region government) KRG for example some amounts of yearly budget after 2003 was coming from the IRAQI Federal governments and other parts was coming from the internal transactions in the Government circles by Singh, (2017), increasing the activity of the companies, employment in many sectors the development and increasing the import and export in many times the population of Kurdistan Region Government was searching for luxury products, in this case we can say all of the factors effected to increasing the capital budget in the private sectors in Kurdistan Region Government in Iraq. Nawid company is started job in Kurdistan Region Government (KRG) in 1998 in Erbil city with capital of $110000 \$$ as the capital with the small business regarding general business such as jobs in cigarette (import) and exported in source of Iraq and importing the fabrics from source of Korea to the Erbil - Kurdistan Region Government (KRG) they distributed in the markets after 2003, Kurdistan Region Government (KRG) developed by many sectors ,Nawid company as one of the companies developed day by day and increased the capital for the company with development many sectors such Financial department, ware house departments (Singh, 2017), administration department because of the Nawid Company could to make more import in the productions out of Iraq to inside Iraq because of the removed blocked economic was decide from United nation, also many of jobs requested in the construction and other sectors more of the financial and economical way was open to the investment sectors in Kurdistan Region Government (KRG) by Singh, (2017). Nawid was one of Investment Company in that time and in Current time decide to increase all kind of activity in the strategy to the last points in the organization structures targets and goals (Singh and Sahin, 2017). Nawid company was decide to put aright numbers in the right place and in the annual budget with of the some points as negative points (put the right numbers in the wrong place ) and put wrong numbers in the right place with taking the important points regarding access petty cash as one of the important financial statements and all the numbers inside this statement in the daily transactions below figures regarding some kind of the statements of Nawid Company with the some negative and positive points and making covering for any negative situation (economy and financial) that effects of financial crisis (Singh and Sahin, 2017).

\section{Negative and positive points of budget private sector in Kurdistan during crisis}

As researcher mentioned in above figure regarding the yearly balance sheet budget overview as of December 31 , 2016 for the Nawid Company general Trade LTD in Erbil-Kurdistan Region Government found that this company have contracts with the governments because of more of the amounts as put inside the banks and the petty cash amounts is a small amounts, as we know after June $2014 \mathrm{KRG}$ have bad situation regarding the negatively situations in the bank transactions and cash transaction circulation in KRG after that most of companies could not receive the cash amounts as loan from the job contract investment with the Kurdistan region government( KRG) by Singh, (2017), those bad points make it negatively actions and points for balance sheet budgets annual overview the private sectors as we seen in balance sheet in Nawid company. The bank amounts put it in the bank is huge amounts ,accounts payable is also a big amount The total current liability in the total months 2016 also is the big amount beside this the petty cash amount and accounts receivable is not huge amounts according to Singh (2008) said that if anyone or any side need to take any information regarding any companies and private sectors should see to the total current assets in yearly budget balance sheet and the total current liabilities in the annual budget balance sheet, if the first section bigger than second section this is mean that the financial situation for this companies is good and going to better opposite that if the total amounts for the second sections are the bigger than first section this is mean this company or this private sector organization really inside the financial crisis and this is bad situation for that company (Cura, Singh, and Talaat, 2017). I am such researcher believe that this role mentioned in the references above is not stable with Nawid company as one of the company in the Iraq-Erbil Middle zone because of there is a different policy (Sahin and Singh, 2017), the policy is the company cannot take their amounts from all of the Kurdistan region government (KRG) banks because of the Financial crisis happen after June 2014 with Coming ISIS to that zones, this is mean that any companies made an agreement for any kind of jobs with Kurdistan region government (KRG), in the previous and finished all type of job correctly and going to the all types of quantity and quality of request from government and Kurdistan region government (KRG) give it the companies all the fund of the contracts inside companies bank accounts (Pattnaik, Mishra, and Singh, 2012), but it's not benefits for private sectors to cannot withdraw all or part amounts inside the bank accounts the effects for this negative points ignition the financial crisis in the private sectors because of the contracts of petty cash 
amounts inside the company's current assets (Singh and Sahin, 2017).

\section{Conclusion}

The current research is consideration of the effect of access petty cash in financial crisis in private sector. In this research the researcher find many of the advantage and disadvantage reasons from the high to the low as affects for access petty ash in financial crisis in the private sector (Mohinta, Singh and Mishra, 2017), for example in the KRG government I believe that the political issue is an active and it has broken down in KRG because of a members of completing political they are agreed to not agreed and they are decided to pending the problems year after year so that it was the strongest point to make KRG's crises. I suggest to the political people to finish the political problems between all colors in the political place in $\mathrm{KRG}$, after that the fundamental of solution financial crises will be started \} of course the solution of the financial crises of the private sector organization will be finish and starting to the growth, because of the projects from the government will start and the amount of money by cash will came to the economy circulation step by step the situation of this bad case of companies will going to solve. I suggest the private sectors working by having a access as a powers of job when they starting negotiation with the government or other kind of the vendors, or taking advance payment part by part when they starting the work in the projects because of the financial crises in KGR government zone will stay until many years. I suggest the private sectors working with the bank for case of financial crises happen in the private sectors to help the companies and organization by giving some amounts as loan for short term or long term.

The current research was restricted to identify the effect of access petty cash in financial crisis in private sector; it might be suitable to state in the small business for the research. In this case the following business sector policy actions may be taken into consideration as an important points: The policy for each country should make the prevention for the phenomena of financial crises to be less effect of the investment sector. All kind of government in the world wide should be finish the political between each to gather. The government should increasing the distribution cash amount as a part of annual yearly budget to far for the financial crisis starting and ignition in the private sector. In the case of KRG government - should be starting the negotiation with Iraqi government to return the $17 \%$ of the budget. The companies and organization should making the cash as more of the percentage of the financial transition because of the access of petty cash has power and actions for companies finance situation and to better finance situation. The companies and private sector organization should make the cash flow statement with correct amount implementation to be positive points for fixing the financial crisis. The companies and private sector organization should making the sales by cash amount opposite that the loan (accounts payable) way.

\section{References}

Arnold, P. J. (2009). Global financial crisis: The challenge to accounting research. Accounting, Organizations and Society, 34(6), pp. 803-809.

Baker, D. (2007) Strategic change management in public sector organizations Elsevier.

Bordo, M., Eichengreen, B., Klingebiel, D., \& Martinez-Peria, M. S. (2001). Is the crisis problem growing more severe? Economic Policy, 16(32), 52-82.

Bradosti H., \& Singh, U.S. (2015). Public awareness of financial market in iraqi kurdistan. European Journal of Business and Management, 7(10), 300-308.

Bradosti, H. \& Singh, U.S. (2015). Predicting the Market Potential Using Time Series Analysis, International Journal of Social Sciences \& Educational Studies, 57.

Brigham, E. F., and Ehrhardt, M. C. (2013) Financial management: Theory \& practice .

Cura. F., Singh, U. S., \& Talaat, K. (2017). Measuring the Efficiency of Tourism Sector and the Effect of Tourism Enablers on Different Types of Tourism (Kurdistan). Turizam, 21(1), 1-18.

Diwan, I. (2001). Debt as Sweat: Labor, Financial Crises, and the Globalization of Capital,

Eichengreen, B., \& Bordo, M. D. (2002). Crises Now and then: What Lessons from the Last Era of Financial Globalization,

Goldin, I., \& Vogel, T. (2010). Global governance and systemic risk in the 21st century: Lessons from the financial crisis. Global Policy, 1(1), 4-15.

Kahle, K. M., and Stulz, R. M. (2013). Access to capital, investment, and the financial crisis. Journal of Financial Economics, 110(2), 280-299.

McKibbin, W. J., \& Stoeckel, A. (2010). The global financial crisis: Causes and consequences. Asian Economic Papers, 9(1), 54-86.

Mohinta, S., Singh, U.S. \& Mishra, U.S. (2017). Retail Store Brand Commitment Study of Big Bazaar or Pantaloons. International Journal of Supply Chain Management, 6(4), 139-145.

Pattnaik, S., Mishra, U.S., \& Singh, U.S. (2012). Inbound logistics: A challenge for steel industry in odisha. The Research Network, 7(2), 33-42.

Prasad, E., Rogoff, K., Wei, S., and Kose, M. A. (2005). Effects of financial globalization on developing countries: 
Some empirical evidence. India's and China's recent experience with reform and growth (pp. 201-228) Springer.

Ross, Sean. "3 Financial Crises In The 21St Century". Investopedia. N.p., 2017, Accessed on :8 Apr. 2017.

RTI, 2008 (Kurdistan region economic development assessments) local government project.

Sahin, O. \& Singh, U.S. (2017). A Literary Excavation of University Brand Image Past to Present. International Journal of Social Sciences and Educational Studies, 3(3), 174-187.

Sahin, O. \& Singh, U.S. (2017). Leadership Practices Effect on University Brand Image: A Study on ISHIK University. Scholars Journal of Arts, Humanities and Social Sciences, 5(9C), 1284-1295.

Sahin, O. \& Singh, U.S. (2018). Measuring the Brand Image Association with Personal and Social Factors for Private Universities. Scholars Journal of Arts, Humanities and Social Sciences, 6(5), 1028-1040.

Sherwani, K., \& Singh, U.S. (2015). Student perception on lecturer evaluation in higher education. International Journal of Social Sciences \& Educational Studies, 49.

Singh, S. (2008). Public finance in theory \& practice S. Chand Publishing.

Singh, U. S. (2013). Sustainability of export: an empirical study on potential of seafood export from odisha. Journal of Management \& Research, 3, 123-133.

Singh, U. S. (2017). A Relational Study on Export Market Orientation and Business Performance. Scholars Journal of Economics, Business and Management, 4(1), 47-61.

Singh, U. S. (2017). A Relational Study on Export Market Orientation and Business Performance. Scholars Journal of Engineering and Technology, 5(1), 27-33.

Singh, U. S. (2017). Analyzing the Acceptability of Customer Relationship Management Practices by Society. Scholars Journal of Arts, Humanities and Social Sciences, 5(1), 58-64.

Singh, U. S. (2017). Analyzing the Quality Management Process in Healthcare Sector, Scholars Journal of Engineering and Technology, 5(1), 27-33.

Singh, U. S. (2017). Volumes and Flows Issue with Vegetable Industry in India. Scholars Journal of Agriculture and Veterinary Sciences, 4(1), 24-31.

Singh, U. S., \& Kamaran, A. (2016). Academic Learning and Early Childhood Behavior. 7th International Visible Conference on Educational Studies \& Applied Linguistics, 9-21. ISSN 978-0-9962570-4-6.

Singh, U. S., \& Mishra, U.S. (2013). Vegetable supply chain: A conceptual study. Food Science and Quality Management, 15, 30-35.

Singh, U. S., \& Mishra, U.S. (2014). Supply chain management through vertical coordination in vegetable industry. International Journal of Supply Chain Management, 3(3), 148-154.

Singh, U. S., \& Mishra, U.S. (2015). Assessment of need for vertical coordination in supply chain of vegetable industry. International Food Research Journal, 22(4), 1417-1423.

Singh, U. S., \& Padhi, S.K. (2013). Factors affecting purchase decision of carpenters for laminates. Asia Pacific Journal of Marketing \& Management Review, 2(6), 59-68.

Singh, U. S., \& Pratap, B.R. (2013). Export potential of seafood from odisha. EXCEL International Journal of Multidisciplinary Management Studies, 3(4), 55-65.

Singh, U. S., \& Yadav, A.K. (2013). Export potential for handloom and handicraft: a study on odisha. International Journal of Research in Computer Application \& Management, 3(4), 141-145.

Singh, U. S., Mishra, U.S., \& Mishra, B.B. (2014). Vertical coordination for optimization of the vegetable supply chain. International Food Research Journal, 21(3), 1387-1394.

Singh, U.S. \& Azad, S. (2019). A Study on the Effect of Pricing Strategy on Customer Retention in Kurdistan. International Journal of Supply Chain Management, 8(1), 98-112.

Singh, U.S. \& Bradosti, H. (2015). Agricultural Sector Financing and Challenges for Bankers. European Journal of Business and Management, 7(33), 1-7.

Singh, U.S. \& Hamadamin, J.F. (2019). Analyzing the Main Marketing Strategies Leading to Customer Satisfaction. International Journal of Supply Chain Management, 8(1), 113-123.

Singh, U.S. \& Sahin, O. (2015). Issues with the Success of Micro Finance. International Journal of Management Research and Business Strategy, 4(4), 146-157.

Singh, U.S. \& Sahin, O. (2015). Modern Human Resource Practices and Industrial Relations. Journal of Resources Development and Management, 13, 106-119.

Singh, U.S. \& Sahin, O. (2015). Value of CRM and Its Benefit to the Cellular Operators. International Management Research and Business Strategy, 14(3), 276-288.

Singh, U.S. \& Sahin, O. (2017 Measuring the Effectiveness of Sales Promotion Activities on Brand Loyalty: A Study on COCA COLA. International Journal of Social Sciences \& Educational Studies, 3(3), 159-173.

Singh, U.S. \& Sahin, O. (2017). Measuring the University Competence Comparatively For Nurturing Future Leaders. Scholars Journal of Economics, Business and Management, 4(6), 669-680.

Singh, U.S. \& Sahin, O. (2019). Assessing the Information System Efficiency of Academic Institution. Scholars Journal of Arts, Humanities and Social Sciences, 7(3), 240-250. 
Singh, U.S. \& Sahin, O. (2019). Relationship Assessment of Colors and Product Selection. Scholars Journal of Arts, Humanities and Social Sciences, 6(3), 266-274.

Singh, U.S. (2015). Importance of Job Satisfaction in Steel Plant. International Journal of Management Research and Business Strategy, 4(4), 130-145.

Singh, U.S. (2015). Marketing Agricultural Produces: A Literature Study of India. Journal of Marketing and Consumer Research, 16, 102-107.

Singh, U.S. (2015). Total Productive Maintenance A Tool for Efficient Production Management. International Journal of Management Research and Business Strategy, 4(3), 289-301.

Singh, U.S. (2018). A Conceptual Approach Correlating Behavioral Neuroscience with Vertically Coordinated Vegetable Supply Chain. Scholars Journal of Arts, Humanities and Social Sciences, 6(5), 1021-1027.

Singh, U.S., \& Bradosti H. (2015). Acceptability of banking operations in iraqi kurdistan. Research Journal of Finance and Accounting, 6(9), 276-286.

Surarchith, N.K. and Singh, U. S. (2013). A study on the service quality and its relation to CRM in telecom industry. Industrial Engineering Letters, 3(5), 50-58.

The official website of Kurdistan region government (2016), The report of the problems of KRG and Iraq budget 2013(comity of finance and economic and investment). 